\section{Psychosocial evolution}

SIR. - In his review of Garland Allen's T.H. Morgan: The Man and His Science (see Nature, 278, 786-787; 1979), Professor Darlington makes several very cogent points. Perhaps the most illuminating of all are his remarks about the relations between Morgan, Wilson and Bateson, which are especially valuable in view of the fact that he knew all three men. It is therefore a great pity that, simply for the sake of taking a rather poorly aimed pot-shot at Allen's Marxism, Professor Darlington drags in the canard of "Lamarikism and Lysenkoism", alleging that both Morgan and Julian Huxley opened the door to these horrors. I do not have Morgan's Scientific Basis of Evolution to hand but what Huxley says on psychosocial evolution in Evolution: The Modern Synthesis (Allen and Unwin: London; second edition, 1963, pp. xliv - xlvii) in no way justifies this ciarge. It might be objected that "psychosocial evolution" is a cumbrous and pretentious phrase for a very simple and obvious phenomenon. Indeed, I would myself prefer simply "cultural evolution", or the phrase that Huxley used clsewhere in a popular essay (The Uniqueness of Man; Allen and Unwin: London; 1941): "cumulative tradition". The idea is a commonplace, for which a list of 'sources'

\section{Cock on evolution}

DR Cock complains that I have wrongly connected the evolutionary views of Morgan and Huxley. And also wrongly connected them with the theories of Lamarck and Lyscriko and with what I called the "froth" of our sccial sciences today. These ideas, he says, are "commonplace" and it is not "necessary or practicable" to trace them to their roots. 1 , however, think it necessary to trace all ideas, scientific or political, true or false, to their roots. I have been trying to do so for over fifty years. May I show how it works?

There were two roots in this case. Morgan had used his reputation as the supposed creator of the theory of heredity to advance a false theory of heredity and evolution in man. And Julian Huxley had used his name to repudiate his grandfather's work in Man's Place in Nature; he was therefore :ble to present himself as the Darwiaian who had discovered that after all we tueed not worry: Darwinism did not apply to man.

Take Morgan first. I did not seriously look at his book when he gave it me in 1933 (I don't think he looked at my book either). But there it stands. It expresses the main fallacies current in human evolutionary thought today. The first fallacy is that "There are in man two processes of inheritance: one through the physical continuity of the germ-cells; and the other through the transmission of the experiences of one generation to the next". The physical inheritance gives you 3:1 ratios and dogmatic truth of interpretation. It applies to bodily characteristics. But (and here is the second fallacy) it does not apply to the brain: "It is the plasticity of man's brain that makes him unique". Then Morgan naturally asks: "Is intelligence inherited?". How can we be sure? There is nature and nurture. And there may be conflict between them. Worse still, there is "the doctrine that all men are born free and equal". All the issues are avoided. All the fallacies are scrambled.

Three years later (in 1936) this kind of loose talk had become dangerous. In Europe genetic assumptions werc being turned to political uses. Half-baked genetic ideas were helping us on the way to war. In this country a particular danger concerned me. Genetic teaching and research hardly existed in our universities. I therefore collected university signatures for a letter in Nature $(138,972-973 ; 1936)$ protesting against academic stagnation in this vital would be neither necessary nor practicable. This is itself sufficierit reason for Huxley not having mentioned Morgan in this connexion. To argue that, because of its radically different nature, it should not be regarded as a form of evolution or of heredity would be difficult in view of the dictionary meanings of those words.

A Lelief in psychosocial evolution is perfectly compatible with the belief that heredity, in the genetical sense, is diamondhard. For Professor Darlington to pretend otherwise is just as absurd as it is tor Arthur Koestler (The Case of the Midwife Toadt Hutchinson; Lordon, 1971) to claim that Waddington's work on genetic assimilation was a vindication of Lamarckism. Nobody who approaches either human history or what is going on in the world today with a relatively unprejudiced mind can doubt that psychosocial evolution is both real and important. To create a fal:e link with Lamarckism is merely to hand the argument to the Lamarckians on a plate.

A.G. Cock

A.G. Cock is Lecturer in the Department of Biology, at the University of Southampton, UK.

respect. I also turned to Huxley who had been aggressively defending che Mendelian and Darwinian positions at the British Assuciation. I persuaded him to edit an international symposium on the developing situation in evolutionary theory. He agresit. But by the time the book appeared in 1940 (under the title of The New Systematics) discovered that Huxley was easing out of the genetic problem so far as man was concerned In We Europeans, followed by the Uniqueness of Man he was looking for a political way out: the kind of 'placebo' that Morgan had stumbled upon.

Faced with this confusion I tried to make my position clear in an article, or manifesto, under the heading of "Race, Class and Mating in the Evolution of Man' (Nature, 152, 315-319; 1943). Here I discussed the complex and often reciprocal or feedback relations of race, culture and selection, as recorded in history but usually misunderstood by historians. I argued that inbreeding always produces groups or communities or races which are the indispensible agents of human evolution.

Each of these "owes its character to what we may call its chromosume pool". I went on to say that "race made culture and language" and that inbreeding led to "easy transmission of culture". In other words the creation and transmission of ideas were both based on hereditary abilities, and both were subject to genetic and selective Mendelian and Darwinian processes.

To justify these ex-cathedra statements I began to set out the historic and pre-historic record of human society in genetic terms. My first essay, The Facts of Life, 1 sent to Huxley in proof, as he had sent me the shapter of his Evolution dealing with my work. He made prodigious annotations, chiefly urging me to qualify my generalisations or weaken my conclusions. I kept the proof but did not adopt the suggestions.

During the next ten years we exchanged a hundred or so letters in which Huxley was enquiring about my views on genetic and evolutionary questions. $A_{1}$ the end of this time (in 1963) he published a second edition of his Evolution, with a new introduction. Here he set out his full UNESCO formula. Now all peoples were to be reconciled to one another, prosperously united under the banner of inevitable scientific progress.

Man had entered a "psychosocial phase of evolution". Change was now "primarily cultural and only secondarily genetic". Each human population had, not my pool of chromosomes, but "a pool of ideas" on which it could draw "for its evolutionary requirements". It was obvious (as 1 explained in the Times Literary Supplement of 20 December, 1974) that in this pastiche Huxley had provided the world with a pool of ideas which would meet the "evolutionary requirements" of the social and political sciences for many years to come. Nor that they would know (any more than Dr Cock does) what pool they were drawing them from.

For there was indeed another pool. The Soviet Government had repudiated Lysenko in agriculture. But Marxists throughout the world continued to draw what unity they had from one surviving belief, the belief that theories of evolution by natural selection did not apply to man. Anathema had been pronounced on 'Social Darwinism' and it could never be withdrawn. So abominable was this heresy that it must always be condemmed; and it must never be discussed.

For these reasons I thought it worthwhile to write another book, The Little Universe of Man (apparently unknown to Dr Cock but reviewed in Nature, 277, 247; 1979). Here argued in elementary terms my genetic view that intelligence is seated in the brian and that the brain is part of the body. Hence men differed in their ability to create culture, to acquire culture and to transmit culture. Not only meir and women as individuals, but as families, classes and races, as sects and groups of all kinds, they differed genetically by their genes and chromosomes in their abilities to do these things. They always had differed and always would differ, a situation responsible for the past history, present state and future prospects of mankind.

In writing these things I took the opportunity again of holding up Huxley's views to the ridicule they invite and deserve. also again returned to expose a minor fallacy of Morgan's which has left a long trail of error behind it. This is the view that all heredity is in the chromosomes and in the nucleus. And that therefore one-egg twins are always identical in heredity. Each step in this argument is false and the conclusion has been repeatedly falsified. But it had become, as I put it (Nature 234, 521-525; 1971) "axiomatic". Because Morgan said it (although he also said intelligence could not be measured) all psychologists trying to measure intelligence have assumed it to be true - and that includes the late Cyril Burt. 1 therefore pointed out, first, that Gaiton, who first recognised one-egg twins, never made Morgan's mistake of supposing they were identical; and secondly, that there are two genetic ways, nuclear and non nuclear, in which we know why they often cannot be identical. The likenesses of one-egg twins, whether measured in mind or body, remarkable as they are, thus always give an under-estimate of the effects of heredity; their differences always give an over-estimate of the effects of environment.

I may now go back to Dr Cock and his sources. I have found that whether in scientific historical or any other discussion, it is always desirable to look for the sources, examine them, and question them; and each step in the argumint that has led from them. And I believe it is because social and politica scientists often fail to do so, finding that the knowledge is "commonplace", or the task not within their "frame of reference", or merely, following the eminent examples of Morgan and Huxley, that so much of what flow: from their enquiries turns out to be froth.

C.D. Darlington

C.D. Darlington is Emeritus Professor of Botany at the University of Oxford, UK. 